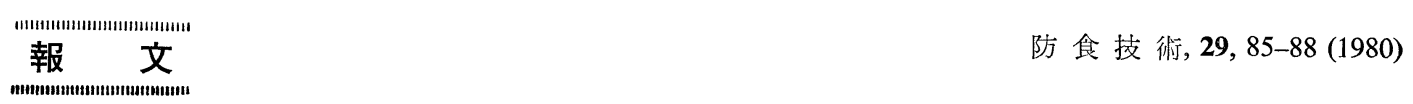

\title{
亜硝酸塩系インヒビターによる $\mathrm{Cr}-\mathrm{Mo}$ 鋼の防食効果 に及ぼす溶存酸素の影響"
}

\author{
三浦健蔵**, 熊田 誠**, 三宅良昭**, 大井利継** \\ **三井造船株式会社玉野研究所
}
Effect of Dissolved Oxygen on Corrosion Inhibition of Cr-Mo Steel Using Sodium Nitrite*

\author{
Kenzo Miura**, Makoto Kumada**, Yoshiaki Miyake** \\ and Toshitsugu $\mathrm{Ohi}^{* * *}$ \\ **Tamano Laboratory, Mitsui Engineering \& Shipbuilding Co., Ltd.
}

\begin{abstract}
The effect of dissolved oxygen on corrosion inhibition of Cr-Mo steel using sodium nitrite, which can be added to the circulating cooling system of marine diesel engines as a corrosion inhibitor, has been investigated in pure water with $50 \mathrm{ppm} \mathrm{SO}_{4}{ }^{2-}$ by means of the polarization resistance method and weight loss and the corrosion potential measurements. In corrosion rates over $10 \mathrm{mdd}$, there was a linear relation logarithmically between corrosion rates and polarization resistance in $\mathrm{NaNO}_{2}-\mathrm{SO}_{4}{ }^{2-}$ ion solutions, and critical values for polarization resistance existed in the corrosion-inhibition interfacial region. When sodium nitrite more than the critical concentration required for corrosion inhibition was added, the good inhibitive effect is obtained. On the other hand, when the sodium nitrite was added under the critical concentration in the solution with high dissolved oxygen corrosion was accelerated by the depolarization of oxygen, but corrosion was retarded with low dissolved oxygen. It can be concluded that the inhibitive action of sodium nitrite results in the formation of the adsorbed layers of nitrite ion and dissolved oxygen stimulating the passivation of the steel surface.
\end{abstract}

\section{1. 緒}

舶用ディーゼル機関冷却水系の腐食環境は非常に蕨し く,シリンダー・カバーやピストンなど燃焼室壁部材の 清水冷却面側に抢腐食損傷の大きな要因となってい る。現在，その防止対策の一環として，冷却水に亜硝酸 塩系インヒビターを添加する方法が採られている1)。亜 硝酸塩系インヒビターは鋼表面に不働態皮膜を形成して 防食する典型的なアノード型インヒビターであるが2), その防食過程や溶存酸素の影響なぞ基礎的な特性につい ては不明な点が多い。

インヒビターの評洒法として従来行われてきた腐食減 量法に対し, 実装置のモニタリング法として注目されつ つある分極抵抗法は，腐食速度と分極抵抗值との関係に よりインヒビターの防食効果の経時的な変化を比較的容 易に判定することができるなど多くの利点を有してい

* 1975 年 5 月, 本協会 '75 春期大会（東京）飞一部 発表

** 䎡706 玉野市玉原 3 丁目 16-1 (16-1，Tamahara 3-chome, Tamano 706, Japan)
る。

本研究では，燃焼室壁部材と同一組成の $\mathrm{Cr}-\mathrm{Mo}$ 鋼を 試料とし，分極抵抗法と腐食電位の測定により亜硝酸塩 系インヒビターの防食効果に及ぼす溶存酸素の影響につ いて検討したので，その結果について報告する。

\section{2. 試料および実験方法}

供試材は化学組成を表 1 に示すような Cr-Mo 鋼で $1050^{\circ} \mathrm{C}, 2$ 時間保持油焼入れ後, $650^{\circ} \mathrm{C}, 6$ 時間保持炉 冷の熱処理を施した。

Table 1. Chemical composition of specimen (wt \%)

\begin{tabular}{c|c|c|c|c|c|c}
\hline C & Si & Mn & P & S & Cr & Mo \\
\hline 0.15 & 0.25 & 0.81 & 0.037 & 0.025 & 1.08 & 0.19 \\
\hline
\end{tabular}

腐食減量の測定には, $20 \times 30 \times 3 \mathrm{~mm}$ の形状の試験片 を用いた。その表面をエメリ一紙 \#120 まで研磨し，エ チルアルコールで脱脂後, 3 枚 1 組として試験溶液中に 
2 6 日間浸漬し, その重量減から平均腐食速度を求め た。分極の測定には $15 \mathrm{~mm} \phi$ の丸棒を樹脂に埋め计み, その断面を電極表面としてバフ研磨し，エチルアルコー ルで脱脂後試験に供した。分極抵抗測定は，定電流 3 電 極法による自作の分極抵抗測定装置で行い，対極に白金 を，標準電極に飽和甘氷電極を用いた。分極抵抗值 $R_{p}$ は次式より算出した。

$$
R_{p}=\Delta E / i_{\mathrm{app} 1 .}
$$

ここで, $\Delta E$ は電極に $0.38 \sim 7.63 \mu \mathrm{A} / \mathrm{cm}^{2}$ のアノードお よびカソード電流 $i_{\mathrm{appl}}$.を流した時の平衡電位からのず れを表わす。ただし過電圧 $\Delta E$ は $0.015 \mathrm{~V}$ 以下とし，電 流 $i_{\mathrm{app} 1}$. の付加時間は 10 秒*とした。な扔電位測定試料 は $10 \% \mathrm{H}_{2} \mathrm{SO}_{4}$ および $20 \% \mathrm{HNO}_{3}$ 中で極く短時間エッ チ後水洗の前処理を行った。

試験溶液は $50 \mathrm{ppm} \mathrm{SO}_{4}{ }^{2-}$ を含むイオン交換水に市販 の亜硝酸塩系インヒビタ一（組成は $\mathrm{NaNO}_{2}: 88 \mathrm{wt} \%$, $\mathrm{Na}_{2} \mathrm{~B}_{4} \mathrm{O}_{7} \cdot 10 \mathrm{H}_{2} \mathrm{O}: 9 \%$, BTA: $1.9 \%$, その他: $1.1 \%$. 以 下 $\mathrm{NaNO}_{2}$ と記す。）を $100 \mathrm{ppm}$ ，あるいは $500 \mathrm{ppm}$ 添 加したものを用いた。前報に括いで，インヒビタ一濃 度 $100 \mathrm{ppm}$ のとき激しい腐食が起こり，500 ppm のと き良好な防食効果が得られることを報告した。そこで本 実験では，大気開放下で腐食の起こる状態（腐食状態と 呼ぶ）として $\mathrm{NaNO}_{2}$ 濃度 $100 \mathrm{ppm}$ を, 腐食の起こら ない状態(防食状態と呼ぶ) として $\mathrm{NaNO}_{2}$ 濃度 $500 \mathrm{ppm}$ を選んだ。

溶存酸素濃度は, 酸素-窒素混合ガスを溶液中に連続的 に通気することにより調整した。 $30^{\circ} \mathrm{C}$ における溶存酸 素濃度は溶存酸素計 (東芝ベックマン(株)製“Fieldlab”) を用いて，試験片浸漬前に混合ガスを通気し定常值に達 した後測定した。 $80^{\circ} \mathrm{C}$ の場合には計器の性能上溶存酸 素計による測定ができなかったため，混合ガス中の酸素 が Henry の法則に従って溶解するものとして溶存酸素 濃度を算出した。

\section{3. 実験結果および考察}

\section{1 分極抵抗值と腐食速度との関係}

分極抵抗法の大きな利点は，腐食系を乱さない程度の わずかな電流 $i_{\mathrm{appl}}$ ．を通電して試料の分極值 $\Delta E$ を測定 し, 腐食速度 $i_{c o r r}$ を求めることが出来ることである。 分極抵抗値 $R_{p}$ は (1) 式のように表わされるが， $\beta_{\mathrm{a}}, \beta_{\mathrm{c}}$ をアノード，カソード反応のターフェル勾配とすれば,

* 分極電流の付加時間について, A.C. Mackrides ${ }^{3)}$ M. Nagayama $5^{4)}$ は，分極電流が微小であっても 長時間付加されると金属表面に溶解，皮膜生成，物 質の吸着など種々の変化を生ずるので，パルス電流 の付加あるいは電気化学的二重層の充電が完了し金 属表面の変化があまり起こらない短かい付加時間 (5〜15 秒程度) が適当であると述べている。 $i_{\text {corr }}$ と $R_{p}$ 值との間に次式が成り立つ ${ }^{5)}$ 。

$$
\begin{aligned}
i_{\text {corr }} & =\beta_{\mathrm{a}} \cdot \beta_{\mathrm{c}} / 2.3\left(\beta_{\mathrm{a}}+\beta_{\mathrm{c}}\right) \times\left(1 / R_{p}\right) \\
& =K \times\left(1 / R_{p}\right), \quad K: \text { const. }
\end{aligned}
$$

従ってあらかじめ腐食速度 $\mathrm{mdd}$ と分極抵抗值 $R_{p}$ との 関係を求めて拈けば， $R_{p}$ 值から腐食状態の追跡やその 定量的な評価が可能となる。

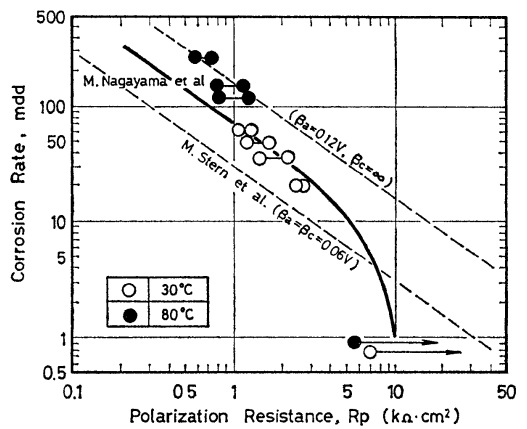

Fig. 1. Correlation between corrosion rates and polarization resistance for $\mathrm{Cr}-\mathrm{Mo}$ steel in neutral solutions.

$\mathrm{NaNO}_{2}$ による $\mathrm{Cr}-\mathrm{Mo}$ 鋼の防食効果に及洼す溶存酸 素の影響を検討するのに先立ち，大気開放条件で浸漬試 験による試験片の重量減から求めた平均腐食速度 mdd と分極抵抗值 $R_{p}$ との関係を調べた。試験溶液の温度は $30^{\circ} \mathrm{C}$ と $80^{\circ} \mathrm{C}$ とし, $\mathrm{NaNO}_{2}, \mathrm{SO}_{4}{ }^{2-}$ の濃度は $10 \sim 100$ ppm 打よび 50〜 500 ppm の範囲内で調整した。な颃図 中の破線はそれぞれ $\beta_{\mathrm{a}}=\beta_{\mathrm{c}}=0.06 \mathrm{~V} ; \beta_{\mathrm{a}}=0.12 \mathrm{~V}, \beta_{\mathrm{c}}=\infty$ とした時の理論直線である7。図 1 に拈いて, $\mathrm{mdd}$ と $R_{p}$ 值との間には $10 \mathrm{mdd}$ 以上の腐食状態で対数的に直 線傾向が認められた。また, H.H. Uhlig \& S. Matsuda ${ }^{8)}$ が防食基準とした $1 \mathrm{mdd}$ 以下の防食状態に括ける $R_{p}$ 值は， $30^{\circ} \mathrm{C}$ のとき $R_{p} \geqq 7.0 \mathrm{k} \Omega \cdot \mathrm{cm}^{2}, 80^{\circ} \mathrm{C}$ のとき $R_{p} \geqq$ $5.4 \mathrm{k} \Omega \cdot \mathrm{cm}^{2}$ である。これらの結果は，図中に実線で示 したクロメート添加溶液中に和ける永山らの実験結果 ${ }^{6)}$ とほぼ同様な傾向である。以下の項では，本系で得られ た mdd と $R_{p}$ 值との関係を用いて $\mathrm{NaNO}_{2}$ の防食効果 について検討した。

\section{2 溶存酸素の影響}

$\mathrm{NaNO}_{2}$ による $\mathrm{Cr}-\mathrm{Mo}$ 鋼の防食効果に及洔す溶存酸 素の影響を調べるため， $\mathrm{NaNO}_{2}-50 \mathrm{ppm} \mathrm{SO}_{4}{ }^{2-}$ イオン 溶液中で溶存酸素濃度（以下 $\mathrm{DO}$ と略す）を変え $R_{p}$ 值 を測定した。

図2, 図 3 に溶液温度 $30^{\circ} \mathrm{C}$ に打忊る $R_{p}$ 值の経時変 化を示す。 $\mathrm{NaNO}_{2}$ 濃度 $100 \mathrm{ppm}$ の場合には（図 2), $\mathrm{DO} \geqq 7.43 \mathrm{ppm}$ に対する $R_{p}$ 值は $5 \mathrm{k} \Omega \cdot \mathrm{cm}^{2}$ 以下とな り, 試料表面に多量の赤錆が発生した。DO の減少とと もに $R_{p}$ 值は増加し $\mathrm{DO} \leqq 0.09 \mathrm{ppm}$ では $R_{p}$ 值は $7 \mathrm{k} \Omega$. 


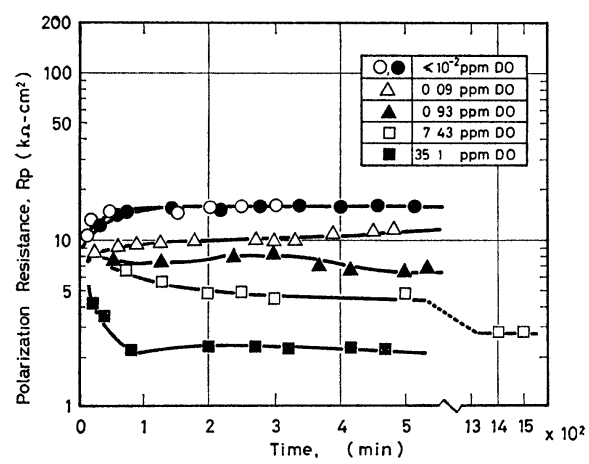

Fig. 2. Time variation of polarization resistance for $\mathrm{Cr}-\mathrm{Mo}$ steel in $100 \mathrm{ppm} \mathrm{NaNO}_{2}-50$ ppm $\mathrm{SO}_{4}{ }^{2-}$ ion solutions containing various dissolved oxygen concentrations at $30^{\circ} \mathrm{C}$.

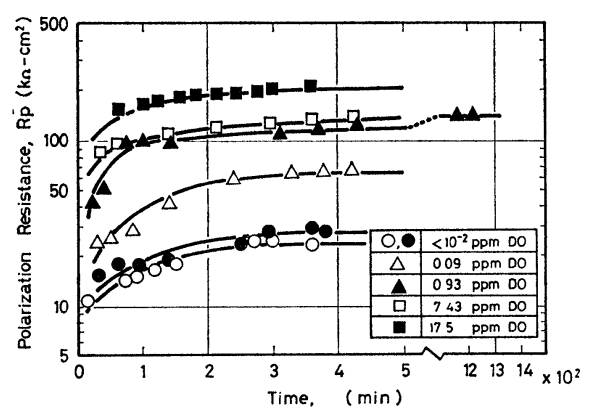

Fig. 3. Time variation of polarization resistance for $\mathrm{Cr}-\mathrm{Mo}$ steel in $500 \mathrm{ppm} \mathrm{NaNO}_{2}-50$ ppm $\mathrm{SO}_{4}{ }^{2-}$ ion solutions containing various dissolved oxygen concentrations at $30^{\circ} \mathrm{C}$.

$\mathrm{cm}^{2}$ 以上となり，防食状態の值を示した。このことから $\mathrm{NaNO}_{2} 100 \mathrm{ppm}$ に护将腐食状態一防食状態の境界の $\mathrm{DO}$ は約 $0.09 \mathrm{ppm}$ と考えられる。一方 $\mathrm{NaNO}_{2}$ が 500 $\mathrm{ppm}$ 添加されると（図 3), すべての DO に対して $R_{p}$ 值は $7 \mathrm{k} \Omega \cdot \mathrm{cm}^{2}$ 以上となり，防食状態の值を示した。 $R_{p}$ 值は $\mathrm{NaNO}_{2} 100 \mathrm{ppm}$ 添加のときと異なり, DO の増加 とともに上昇した。

図 4, 図 5 に溶液温度 $80^{\circ} \mathrm{C}$ に打ける $R_{p}$ 值の経時変 化を示す。 $80^{\circ} \mathrm{C}$ の場合も $30^{\circ} \mathrm{C}$ の場合と同様な傾向で ある。 $\mathrm{NaNO}_{2} 100 \mathrm{ppm}$ では, $\mathrm{DO}=2.90 \mathrm{ppm}, 7.02 \mathrm{ppm}$ に対する $R_{p}$ 值は図 4 に示すように浸漬初期に急激に減 少したのち若干上昇しているが，浸漬初期に激しい腐食 が起こり，その後腐食生成物が試料全面を覆って腐食速 度を低下させたためと考劣られる。同様な傾向は図 2 の DO が 35.1 ppm の場合にも見られる。な和腐食状態一 防食状態の境界の DO は約 $0.04 \mathrm{ppm}$ である。一方 $\mathrm{NaNO}_{2} 500 \mathrm{ppm}$ 添加では, $30^{\circ} \mathrm{C}$ の場合と同様すべて の DO に対して $R_{p}$ は $7 \mathrm{k} \Omega \cdot \mathrm{cm}^{2}$ 以上の防食状態の值

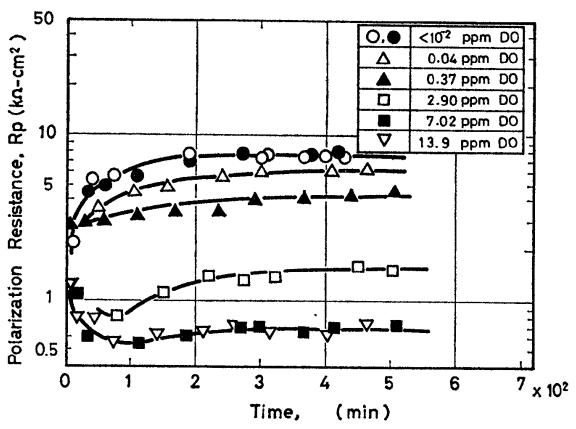

Fig. 4. Time variation of polarization resistance for $\mathrm{Cr}-\mathrm{Mo}$ steel in $100 \mathrm{ppm} \mathrm{NaNO}_{2}-$ $50 \mathrm{ppm} \mathrm{SO}_{4}{ }^{2-}$ ion solutions containing various dissolved oxygen concentrations at $80^{\circ} \mathrm{C}$.

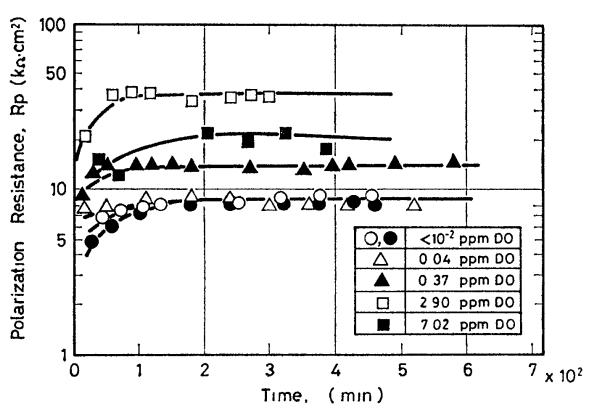

Fig. 5. Time variation of polarization resistance for $\mathrm{Cr}-\mathrm{Mo}$ steel in $500 \mathrm{ppm} \mathrm{NaNO}_{2}-$ $50 \mathrm{ppm} \mathrm{SO}_{4}{ }^{2-}$ ion solutions containing various dissolved oxygen concentrations at $80^{\circ} \mathrm{C}$.

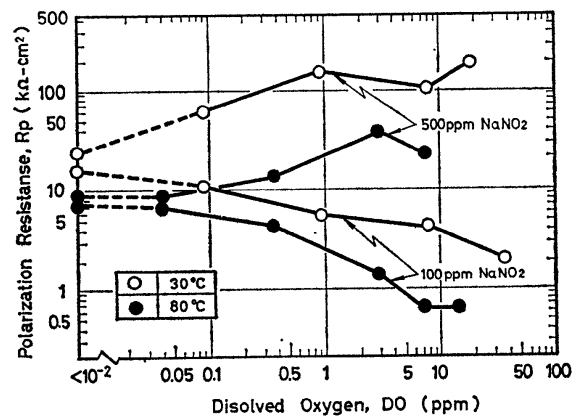

Fig. 6. Effect of dissolved oxygen concentration on polarization resistance for $\mathrm{Cr}-\mathrm{Mo}$ steel in $\mathrm{NaNO}_{2}-50$ ppm $\mathrm{SO}_{4}{ }^{2-}$ ion solutions.

を示し，なた $\mathrm{DO}$ の増加とともに $R_{p}$ 值は上昇した。

$R_{p}$ 值は, 試験片を溶液中に浸漬後 $300 \sim 500$ 分を経過 すると一定值に落着く。従って, 500 分経過時の $R_{p}$ 值 を用いてDOとの関係を整理した。その結果を図 6 に示 した。100 ppm $\mathrm{NaNO}_{2}-50$ ppm $\mathrm{SO}_{4}{ }^{2-}$ 溶液中に沶いて, 
DO がわずかな場合には腐食は抑制されるが，DO が増 加すると酸素による “復極作用” のため腐食が加速さ $れ^{9,10)}, R_{p}$ 值は低下寸る。一方, $500 \mathrm{ppm} \mathrm{NaNO}_{2}$ 溶液 中ではすべての DO に対して防食状態が認められ，DO の增加とともに $R_{p}$ 值は増加した。すなわち $\mathrm{NaNO}_{2}$ が 防食限界濃度1) 以上存在すれば，溶存酸素によって不働 態皮膜の形成が促進され，ょり安定な防食状態になるる のと考兄られる。以上の上うに溶存酸素は充分な濃度の $\mathrm{NaNO}_{2}$ が存在すると腐食を抑制し，不充分な濃度では 腐食を促進する相反する作用のあることが確認された。 また $30^{\circ} \mathrm{C}$ と $80^{\circ} \mathrm{C}$ に抢訬る $\mathrm{NaNO}_{2}$ の防食効果につい て同一 DO に対する $R_{p}$ 值で比較したところ, $80^{\circ} \mathrm{C}$ の 場合に比べ $30^{\circ} \mathrm{C}$ の $R_{p}$ 值の方が全般的に高いことか ら, $\mathrm{NaNO}_{2}$ の防食効果は $80^{\circ} \mathrm{C}$ より $30^{\circ} \mathrm{C}$ の場合の方 が良好であるように考觉られる。

次に $\mathrm{Cr}-\mathrm{Mo}$ 鋼の腐食電位に及法す溶存酸素の影響 を, $500 \mathrm{ppm} \mathrm{NaNO}_{2}-50 \mathrm{ppm} \mathrm{SO}_{4}{ }^{2-}$ 溶液中で検討した 結果を図 7 に示す。

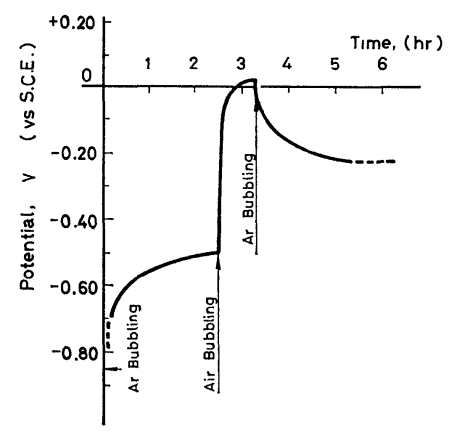

Fig. 7. Effect of dissolved oxygen on corrosion potential for $\mathrm{Cr}-\mathrm{Mo}$ steel in $500 \mathrm{ppm}$ $\mathrm{NaNO}_{2}-50 \mathrm{ppm} \quad \mathrm{SO}_{4}{ }^{2-}$ ion solution at $30^{\circ} \mathrm{C}$.

$\mathrm{NaNO}_{2}$ 添加水中において試料の電位は, 脱気状態で $-0.80 \mathrm{~V}$ (vs S.C.E.) から $-0.50 \mathrm{~V}$ まで上昇した。空気 を吹き込むと, $\mathrm{NaNO}_{2}$ と溶存酸素との共存効果により 電位はさらに貴な方へ移向し $(+0.025 \mathrm{~V})$, その後 $\mathrm{Ar}$ ガ スを吹き込んで再び脱気しても $-0.25 \mathrm{~V}$ まで低下する が，空気吹き込夰前の元の電位 $(-0.50 \mathrm{~V})$ には戻らなか った。このように腐食電位の挙動に溶存酸素と $\mathrm{NaNO}_{2}$ との密接な関係が認められたが，浸漬初期に打ける脱気 状態での電位上昇 $(-0.80 \mathrm{~V} \rightarrow-0.50 \mathrm{~V})$ は $\mathrm{NO}_{2}$-イオ ンの吸着によるものであり, また空気吹き込及後 $\mathrm{Ar}$ ガ スによる再脱気にもかかわらず試験片の電位が元の電位
より貴な值を示すのは， $\mathrm{NaNO}_{2}$ による鋼の防食過程に

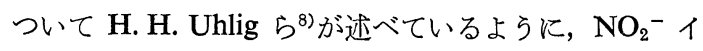
オンと溶存酸素との吸着層の形成と, これにつづく不働 態皮膜の形成によるものと考觉られる。

\section{4. 結 論}

$\mathrm{NaNO}_{2}$ による $\mathrm{Cr}-\mathrm{Mo}$ 鋼の防食効果に及法す溶存酸 素の影響について，分極抵抗法と腐食電位の測定により 検討した結果を要約すると次のとおりである。

(1) $\mathrm{NaNO}_{2}-50 \mathrm{ppm} \mathrm{SO}_{4}{ }^{2-}$ 溶液中に拉いて, 腐食 速度 $\mathrm{mdd}$ と分極抵抗值 $R_{p}$ との間には $10 \mathrm{mdd}$ 以上の 腐食状態で対数的な直線関係が認められ，腐食状態-防 食状態の境界で分極抵抗の境界值が存在する。

（2） $\mathrm{NaNO}_{2}$ が防食限界濃度以上添加されている場 合, 溶存酸素は不働態化を促進し, 非常に良好な防食状 態が得られる。

(3) $\mathrm{NaNO}_{2}$ の添加が防食限界濃度以下の場合, 溶 存酸素が多量に存在すると, 酸素の復極作用に上って激 しい腐食を生ずるが，微量ならば腐食反応は抑制され る。

（4） $\mathrm{NaNO}_{2}$ による鋼の防食作用は，H. H. Uhlig ら冬が提唱しているように, $\mathrm{NO}_{2}^{-}$イオンと溶存酸素の 吸着層を形成することにより鋼表面の不働態化を促すも のと考觉られる。

(Received September 22, 1979)

\section{文献}

1) 三浦健藏, 熊田 誠, 三宅良昭, 大井利継：防 食技術, 27, 385 (1978).

2) 鈴木 隆：材料, 23, 912 (1974).

3) A. C. Mackrides: CORROSION-NACE, 29, 148 (1973).

4) M. Nagayama, K. Goto, Y. Otake \& Y. Kawazu 防食技術, 23, 57 (1974).

5) M. Stern \& A. L. Geary： J. Electrochem. Soc., 104, 56 (1957).

6) 川村静夫, 田中憲明, 永山政一：防蝕技術, 22, 500 (1973).

7) M. Stern \& E. D. Weisert: Proc. Am. Soc. Test. Mat., 59, 1280 (1959).

8) H. H. Uhlig \& S. Matsuda: J. Electrochem. Soc., 111, 156 (1964).

9) R. Pyke \& M. Cohen: J. Electrochem. Soc., 93, 63 (1948).

10) M. Cohen, R. Pyke \& P. Marier: J. Electrochem. Soc., 96, 254 (1951). 